\title{
'Tenshillingland': Community and Commerce, Myth and Madness in the Modern Scottish Novel
}

\section{Scott Lyall}

In Scott Lyall (ed.), Community in Modern Scottish Literature (Leiden | Boston: Brill | Rodopi, 2016), pp. 1-24.

\section{Abstract}

While 'community' as a concept has come under increasing attack in a neoliberal era, it has remained in Scotland a mythic, though not unexamined, signifier of resistance to perceived threats to national identity. Community, central to the Scottish novel since the Kailyard, continues to be a prevalent theme in the many important novels of the twentieth and twentyfirst centuries explored here. Yet, while often disturbingly oppressive in tenor, many of these representations of community actually attack the myth of Scottish communalism to critique, and often expose as forms of madness, the conventional values of social class, capitalism, patriarchy, and religion.

Keywords

Community, Scotland, myth, Kailyard, commercialism, The House with the Green Shutters, Calvinism, madness, class, Sunset Song, Imagined Corners, The Prime of Miss Jean Brodie, capitalism, Lanark, Trainspotting, Tales from the Mall, Scottish politics

\section{The Myth of Scottish Communalism}

If there is an American Dream, 'a narrative of considerable power which helps to define Americans to themselves, and they hope to other people', what, asks David McCrone, is the 
'Scottish myth'? ${ }^{1}$ McCrone makes clear that by myth he does not mean 'something which is manifestly false'. ${ }^{2}$ While he acknowledges that myths 'represent a collection of symbolic elements assembled to account for and validate a set of social institutions', nonetheless neither is he using the term myth in entirely the same semiological sense as Barthes, who seeks the demythologisation of the everyday in order to expose as ideological what is often passed off as natural. ${ }^{3}$ For McCrone, myths resemble traditions in having a complex connection with the past which also informs how we make sense of the present. As such, myths are neither true or false, refutable or irrefutable in any empirical sense, but rather provide tacit credence for certain aspects of self-definition and stereotype in relation to communal or national belonging. In this regard, as Gerard Carruthers points out, '[w]e find such active myths as the "fighting Scot", the "freedom-loving Scot", the "primitive Scot", the "puritanical Scot" and the "civilised Scot", ${ }^{4}$ However, '[i]n the Scottish myth,' according to McCrone, 'the central motif is the inherent egalitarianism of the Scots'.

The importance of Scottish egalitarianism to Scottish identity, society and politics has distinct implications for an understanding of what community might mean in Scotland and in representations of community in Scottish literature, in the same mythic terms outlined above. McCrone has been influenced in his thinking here by Stephen Maxwell, who in an essay entitled 'Can Scotland's Political Myths Be Broken?' from 1976 - three years before the 'No' to Scottish devolution was returned in 1979 - argued that '[p]rovincial Scotland, denied the opportunity of defining its sense of national identity through the exercise of self-government, drugged itself with consoling myths'. ${ }^{6}$ According to Maxwell,

\footnotetext{
${ }^{1}$ David McCrone, Understanding Scotland: The Sociology of a Nation, 2nd edn (London and New York: Routledge, 2001), p. 90.

${ }^{2}$ McCrone, Understanding Scotland, p. 91.

${ }^{3}$ McCrone, Understanding Scotland, p. 91. See Roland Barthes, Mythologies, trans. by Annette Lavers (London: Vintage, 2000), pp. 11-12.

${ }^{4}$ Gerard Carruthers, Scottish Literature (Edinburgh: Edinburgh University Press, 2009), p. 2.

${ }^{5}$ McCrone, Understanding Scotland, p. 91.

${ }^{6}$ Stephen Maxwell, The Case for Left Wing Nationalism: Essays and Articles (Edinburgh: Luath Press, 2013), pp. 15-20 (p. 15).
} 
The idea that Scottish society is egalitarian is central to the myth of Scottish democracy. In its strong nationalist version, class division is held to be an alien importation from England. In the weaker version it describes the wider opportunity for social mobility in Scotland as illustrated in the 'lad o' pairts' tradition. ${ }^{7}$

Maxwell is suggesting that the Scots see themselves as an essentially classless and more democratic people than the English, with pernicious social stratification being introduced through union with England and the subsequent anglicisation of Scottish life. However, in spite of this, core areas of civic life in Scotland retain a uniquely Scottish egalitarian tradition, such as the education system, where talented students can succeed whatever their social background. McCrone takes these ideas forward in his own analysis, pointing out that it is contradictory to imagine Scotland as being at once a classless society and a place where class is no barrier to advancement for the lad o' pairts, who can only ever be a relatively select few. However, McCrone stresses that the nature of the egalitarian Scottish myth 'lends itself to conservative as well as to radical interpretations': if Scots are intrinsically equal, all 'Jock Tamson's bairns', then this can be construed as a call to radically reform the social system along equalitarian lines; yet it can also be seen as a symbol of spiritual equivalence that, in lived social reality, remains sublimely unperturbed by the continuance of a hierarchical status quo. ${ }^{8}$ This second reading is key to what Maxwell means when he says that

The historical accuracy of a myth is [...] less interesting than the political use to which it is put. The Left's favourite myth yields an obvious anti-nationalist conclusion. The

\footnotetext{
${ }^{7}$ Maxwell, The Case for Left Wing Nationalism, p. 17.

${ }^{8}$ McCrone, Understanding Scotland, p. 91.
} 
only force which contains the Scotsman's Calvinist genius for social reaction is England's benign and progressive influence and the main obstacle to political reaction in Scotland is the united British labour movement. ${ }^{9}$

Maxwell's reference to Calvinism is echoed in McCrone's belief that the egalitarian myth has an 'almost mystical element'. ${ }^{10}$ However, while Maxwell points to the perception of Scottish Calvinism as reactionary, McCrone links a democratic instinct to the centrality of the Kirk in Scottish community, a belief fostered by Kailyard representations ( - as Ian Campbell points out, 'Churchgoing, decent rational practical Christianity, are the staples of kailyard society'). ${ }^{11}$ Ironically, the Kailyard, which has so often been characterised as aesthetically, culturally and politically backward-looking, a force inhibiting of radical progress towards Scottish self-determination, especially by writers for the revival of Scottish letters in the early twentieth century such as the nationalist Hugh MacDiarmid, has also been a keeper of communitarian values central to the continuance of the equalitarian myth. If ' $[\mathrm{t}]$ he Scottish myth of egalitarianism survived because it kept alive a sense of national identity', as McCrone argues, then the Kailyard played its own particular role in keeping the pulse ticking. $^{12}$

\section{The Kailyard Community}

To the 'mythic structures' of 'tartanry' and the Kailyard that McCrone argues had for so long been the basis of debates on culture in Scotland can be added the category of community. ${ }^{13}$ If McCrone is correct in his thesis that the Scottish myth supported a continuing sense of national identity this is because Scotland has had no independent national state community

\footnotetext{
${ }^{9}$ Maxwell, The Case for Left Wing Nationalism, p. 16.

${ }^{10}$ McCrone, Understanding Scotland, p. 91.

${ }^{11}$ Ian Campbell, Kailyard: A New Assessment (Edinburgh: The Ramsay Head Press, 1981), p. 14.

${ }^{12}$ McCrone, Understanding Scotland, p. 95.

${ }^{13}$ McCrone, Understanding Scotland, p. 131.
} 
since the Union, and so community-as-myth and nation-as-class have acted as surrogates in the cultural imagination for nation-as-state. (This resounded in the manner in which the Yes movement was represented, and saw itself, as a social democratic communal front during the run-up to the 2014 Scottish independence referendum, and the way in which many artists in Scotland have understood their role in political terms. ${ }^{14}$ ) 'Community', as Timothy C. Baker puts it, 'is both an idea located in a particular history and the replacement of that history. ${ }^{15}$ It is the Kailyard which has been foundational in the modern era in representing Scottish community in these mythic terms.

The Kailyard's centrality to ideas of community in modern Scottish literary culture creates certain paradoxes that find their focus around the figure of the lad o' pairts. The lad o' pairts - the gifted male pupil who, through the community's financial help, is enabled to go to university - occupies an ambivalent space in relation to the rest of the community not dissimilar to that of his author, the Kailyard writer. In supporting the lad o' pairts to get out of the community through education, the community illustrates at once its communitarian solidarity with one of its own and its understanding that the community's elite - 'the crème de la crème' proclaimed by Spark's Jean Brodie - should be released from the limits and ordinariness of community experience. ${ }^{16}$ The Kailyard community thus shows its moral virtue as a place that recognises the value of education and aspiration, and its material shortcomings as a place where such ambitions cannot be fulfilled. When in 1978 Francis Russell Hart wrote that ' $[\mathrm{t}]$ rue community, for the Scottish imagination, is small', he meant that the representational focus of the modern Scottish novel had fallen largely upon the village and small-town community, something that was mostly to remain the case until the publication of Alasdair Gray's Lanark in 1981 and the increased popularity of urban writing

\footnotetext{
${ }^{14}$ For the latter, see Unstated: Writers on Scottish Independence, ed. by Scott Hames (Edinburgh: Word Power, 2012).

${ }^{15}$ Timothy C. Baker, George Mackay Brown and the Philosophy of Community (Edinburgh: Edinburgh University Press, 2009), p. 9.

${ }^{16}$ Muriel Spark, The Prime of Miss Jean Brodie (London: Penguin, 2000), p. 8.
} 
from the 1980s onwards; but also that there has been what Hart calls an 'ironic anticosmopolitan impulse' pervading the Scottish novel that finds its homespun apotheosis in the Kailyard. ${ }^{17}$ The Kailyard community is not only physically small but fundamentally limiting for the lad o' pairts, with the Kailyard as both mythic egalitarian community on the one hand and feeder for elite individualism (disguised as Calvinist meritocracy) on the other. This point is exemplified by the opening story of Ian Maclaren's Drumtochty tales, Beside the Bonnie Brier Bush, 'the quintessential work of the Kailyard'. ${ }^{18}$ In 'Domsie', the lad o' pairts, George Howe, has his university fees paid by the local community, an act orchestrated by the schoolmaster, Patrick Jamison, the Domsie of the title:

There was just a single ambition in those humble homes, to have one of its members at college, and if Domsie approved a lad, then his brothers and sisters would give their wages, and the family live on skim milk and oat cake, to let him have his chance. ${ }^{19}$

The sacrificial nature of the community's actions in ensuring that a special one amongst them goes on to university mirrors the Christian values of the Kailyard ('Ian Maclaren' was the pseudonym of the Reverend John Watson). When the lad o' pairts leaves the village, he carries the community with him as part of his moral value-system, thus representing the community to the outside world just as the Kailyard author fictionally represents the community. In death, George-as-hero is not only returned by his fictional maker to his spiritual maker, he is also returned to the community which is his moral maker. In the authorlad o’ pairts the Kailyard community seeks its own impossible transcendence.

\footnotetext{
${ }^{17}$ Francis Russell Hart, The Scottish Novel: From Smollett to Spark (Cambridge, MA: Harvard University Press, 1978), p. 402.

${ }^{18}$ Andrew Nash, 'Introduction', Ian Maclaren, Beside the Bonnie Brier Bush (Glasgow: Kennedy \& Boyd, 2009), pp. ix-xvi (p. ix).

${ }^{19}$ Maclaren, Beside the Bonnie Brier Bush, p. 7.
} 
Beside the Bonnie Brier Bush, along with other Kailyard works, 'offers a celebration of community values', according to Andrew Nash, as well as an 'idealistic view of a selfsupporting community'. ${ }^{20}$ The unified, organic nature of the Kailyard community not only suggests nostalgia for a lost sense of past community - Maclaren's Beside the Bonnie Brier Bush, for instance, while published in 1894, is set in the 1860s - but also glosses over many of the social divisions both within such small communities and in the larger urban centres of the late nineteenth century when much Kailyard fiction was written. While suggesting that Kailyard fictions are intended as 'morally improving [...] fairy tales', Gillian Shepherd states that '[i]n the Kailyard Eden the only serpents were the implicit threat of distant, urban squalor, poverty, riot and unrest, industrialisation and secularisation' ${ }^{21}$ Social class is undoubtedly the cuckoo in the Kailyard's nest. 'Class distinctions are an important, if tacit, feature of kailyard', according to Campbell, while McCrone goes further, claiming that the 'political economy of the community inhabited by lads o' pairts is pre-capitalist' and '[t]he image of social identity which is held up for praise [in the Kailyard] is one of community, not class'. ${ }^{22}$ McCrone's point - that 'community', as a mythic signifier of prelapsarian unity before the fall into the class discord of industrialisation, obviates class distinctions - is an important one, and worth quoting at length. In the Kailyard community,

The commitment is to the parish, secular and religious, made up of sturdy and selfsustaining individuals. The social hierarchy of the parish is not questioned, and differences of economic and social power are taken for granted, rather than resented. Material rewards may even bring social and psychological disbenefits, if the social duties and obligations which wealth brings are not carried out. The unalloyed pursuit

\footnotetext{
${ }^{20}$ Nash, 'Introduction', Beside the Bonnie Brier Bush, pp. x, xi.

${ }^{21}$ Gillian Shepherd, 'The Kailyard', in The History of Scottish Literature, Vol. 3: Nineteenth Century, ed. by Douglas Gifford (Aberdeen: Aberdeen University Press, 1989), pp. 309-18 (p. 312).

${ }^{22}$ Campbell, Kailyard, p. 13. Italics in original. McCrone, Understanding Scotland, p. 99.
} 
of profit offends the moral economy of the community (as the anti-Kailyard novels at the turn of this [the twentieth] century by George Douglas Brown, The House with the Green Shutters (1901), and by J. McDougall Hay, Gillespie (1914) set out to show. In this regard, they share the scepticism of Kailyard writers like Ian MacLaren [sic] with his suspicion of 'mercantile pursuits'). ${ }^{23}$

The House with the Green Shutters has, as McCrone suggests, been interpreted principally as Douglas Brown's attack on the Kailyard. This view has been encouraged by the author himself: after the novel's publication he wrote that he believed it to be 'more complimentary to Scotland [...] than the sentimental slop of Barrie, and Crockett, and Maclaren' and that it was 'antagonism to their method' that compelled him to make the book so tragically dark. ${ }^{24}$ Young John Gourlay, forced to go to Edinburgh University against his will to satisfy his father's competitiveness with his rival James Wilson, is a botched lad o' pairts, and the 'nippy locality' of Barbie, which is characterised almost solely by spiteful gossip and backbiting, is the antithesis of the absurdly sentimental rendering of community found in the Kailyard. ${ }^{25}$ However, the novel is much more than simply a bomb thrown into the heart of the Kailyard community. Carruthers, for instance, proposes along poststructual/postmodern lines that The House with the Green Shutters 'might be read as a kind of game' that 'shifts around in its mode [...thus] visiting upon the kailyard genre a shower of over-wrought literary modes' which undermine the novel's reputation for literary naturalism. ${ }^{26}$ This has the merit of freeing the text from interpretative reliance on the national traditional and the Kailyard, but somewhat misses the primary point of what has been masked by the novel's Scottish overdetermination. We have seen in McCrone's concept of the

\footnotetext{
${ }^{23}$ McCrone, Understanding Scotland, p. 99.

${ }^{24}$ George Douglas Brown, letter of 24 October 1901, quoted in James Veitch, George Douglas Brown (London: Herbert Jenkins, 1952), p. 153.

${ }^{25}$ George Douglas Brown, The House with the Green Shutters (Edinburgh: Polygon, 2005), p. 107.

${ }^{26}$ Carruthers, Scottish Literature, p. 163.
} 
Scottish myth of egalitarianism that class is shrouded through ideological recourse to 'community'. Equally, the priority of the Kailyard community in interpretations of The House with the Green Shutters has disguised the extent to which the novel is actually a masterful critique of nineteenth-century commercial capitalism and its destructive effects on individuals and communities. Cairns Craig argues that, in the shadow of Calvinism, 'the potency of fear remains central to Scottish culture'; in particular, 'Douglas Brown's world of small-town Scotland is dominated by the word "fear". ${ }^{27}$ Fundamental to The House with the Green Shutters for Craig is the dialectic of fearful community (Barbie) and fearless individual who stands outside or against the community (Gourlay). He contends that even after Gourlay's death, 'the house of Gourlay keeps its fearful dominance over the chorus of the fearing and allows no exit from a dialectic in which the fearful and fearless continually define and destroy each other'. ${ }^{28}$ The fearfulness of the Scottish community has, for Craig, been inherited from the all-pervasive, God-fearing 'imaginative world that Calvinism projected'. ${ }^{29}$ However, while this may have credence at an historical level, it is less convincing as interpretation of a novel that, as Craig himself acknowledges, is governed by a pre-Christian ethic presided over by the terrible fatedness central to Greek tragedy. ${ }^{30}$ Rather than something to be feared, Christianity generally, and Presbyterianism in particular, are little more than a bad joke in the community of The House with the Green Shutters: the gossiping Deacon of the Presbyterian Church talks with a lisp that distorts the Word of God; the Cross no longer symbolises Christ's sacrifice, but is a place where, Judas-like, the town 'bodies' gather to backstab and betray their fellow townsfolk; the Free Kirk minister is denigrated; ${ }^{31}$ and the Bible readings at the end of the novel, often seen as an indication of the Christian love and

\footnotetext{
${ }^{27}$ Cairns Craig, The Modern Scottish Novel: Narrative and the National Imagination (Edinburgh: Edinburgh University Press, 1999), pp. 37, 48.

${ }^{28}$ Craig, The Modern Scottish Novel, p. 51.

${ }^{29}$ Craig, The Modern Scottish Novel, p. 37.

${ }^{30}$ See Craig, The Modern Scottish Novel, p. 48.

${ }^{31}$ Douglas Brown, The House with the Green Shutters, p. 70.
} 
charity lacking in the Barbie community, are recited by Mrs Gourlay and her son in a 'high exaltation of madness' that parodies Kailyard deathbed scenes. ${ }^{32}$ When a minister actually speaks - “"At the Day of Judgment, my frehnds," said Mr Struthers; "at the Day of Judgment every herring must hang by his own tail!"” - it is to express an individualistic ethos that the novel's narrator admits has as much to do with the 'keen spirit of competition' as it has with the fear of God. ${ }^{33}$

The governing dialectic of the Barbie community is not the Calvinist dialectic of fearfulness and fearlessness identified by Craig but the master-slave dialectic of capitalism. Gourlay may appear to be master of the community, Barbie's 'greatest man', but he is as much a slave to encroaching commercialisation and modernisation as are the town's meanest bodies. ${ }^{34}$ Douglas Brown's novel is shot through with allusions to the growing capitalist impulse of the era, from the beginning of the railways to the use of English as opposed to Scots favoured by the likes of Wilson. The Scot is identified as 'largely endowed with the commercial imagination', enabling him to see 'a railway through the desert where no railway exists, and mills along the quiet stream', and it is Wilson, Gourlay's nemesis, who proves in this regard to have the larger vision. ${ }^{35}$ Although, the coming of the railway to Barbie is not merely Gourlay's downfall; as Zygmunt Bauman points out, 'a breach in the protective walls of community became a foregone conclusion with the appearance of mechanical means of transportation'. ${ }^{36}$ Competitive commercialism and the desire for individual gain even infects personal relations, as one of the bodies tells how Gourlay came to marry his wife:

'I ken fine how he married her,' said Johnny Coe. 'I was acquaint wi' her faither, auld Tenshillingland owre at Fechars - a grand farmer he was, wi' land o' his nain, and a

\footnotetext{
${ }^{32}$ Douglas Brown, The House with the Green Shutters, p. 290.

${ }^{33}$ Douglas Brown, The House with the Green Shutters, pp. 74, 75.

${ }^{34}$ Douglas Brown, The House with the Green Shutters, p. 44.

${ }^{35}$ Douglas Brown, The House with the Green Shutters, p. 114.

${ }^{36}$ Zygmunt Bauman, Community: Seeking Safety in an Insecure World (Cambridge: Polity, 2012), p. 13.
} 
gey pickle bawbees. It was the bawbees, and not the woman, that Gourlay went after! It was her money, as ye ken, that set him on his feet, and made him such a big man. He never cared a preen for her, and then when she proved a dirty trollop, he couldna endure her look! That's what makes him so sore upon her now. And yet I mind her a braw lass, too,' said Johnny Coe the sentimentalist $\left[\ldots . .{ }^{37}\right.$

Johnny Coe deploys an infamous levelling tactic and one of the more negative traits buttressing the Scottish egalitarian myth: 'I kent his (or her) faither', a jealous expression of contempt used to put down those who, especially from humble beginnings, have gone on to find success. Mrs Gourlay's father, 'auld Tenshillingland', is named after his farm, as was traditional; that it was also customary to name the farm after the worth of the land illustrates the deeply embedded nature of commercial values in the life of rural communities. The sentimentalism of Johnny Coe's reminiscences - 'She [Mrs Gourlay] had a cousin, Jenny Wabster, that dwelt in Tenshillingland than, and mony a summer nicht up the Fechars Road, when ye smelled the honey-suckle in the gloaming, I have heard the two o' them tee-heeing owre the lads thegither' - not only idealises the past and suggests how much happier Mrs Gourlay (and the community) was then, but in so doing evokes Kailyard prose by the likes of S. R. Crockett in The Lilac Sunbonnet (1894): 'No lassie in all the hill country went forth more heartwhole into the June morning than Winsome Charteris'. ${ }^{38}$ The inscription of commercial value as shorthand for the farmer's true identity suggests, however, that such sentimental idealisation acted to mask much of the more hard-edged realities of nineteenthcentury rural life, much as 'feeling' formed the literary countervail to the onset of industrialisation in the last decades of the eighteenth century. Likewise, the sentimental Kailyard, with the mythic community at its centre, is itself a product of the commercial

\footnotetext{
${ }^{37}$ Douglas Brown, The House with the Green Shutters, p. 78. Italics in original.

${ }^{38}$ Douglas Brown, The House with the Green Shutters, p. 78. S. R. Crockett, The Lilac Sunbonnet: A Love Story (New York: D. Appleton and Company, 1894), p. 28.
} 
imagination of the nineteenth-century Scot satirised in The House with the Green Shutters. Craig complains that '[w] hat makes Douglas Brown's novel so bleak as a projection of the national imagination is that there is no character within the community who is capable of representing, let alone sustaining, the author's values' ${ }^{39}$ In Barbie capitalist individualism promotes competitive spite. Yet the baker (the maker of bread, that staple and sustainer of life), whilst a minor character, a Burnsian like his author, trades the false sentiment of the Kailyard for sympathy and in so doing offers a humane model of what community should be, one that provides an antidote to the malevolence poisoning Barbie: 'folk should be kind to folk', ${ }^{40}$

\section{The Madness of Calvinist Community}

The Kailyard community remained an important antagonistic spur to the movement for literary revival of the 1920-40s, itself influenced by the anti-Kailyard resonances of Douglas Brown's novel. Lewis Grassic Gibbon positions the small community of Kinraddie ‘between a kailyard and a bonny brier bush in the lee of a house with green shutters' in Sunset Song (1932). ${ }^{41}$ That it is the minister who makes these literary allusions to his baffled congregation is germane, for Sunset Song - notwithstanding the admiration shown in the novel for the Presbyterian Covenanters - is about the largely malign influence of religion, specifically Calvinism, upon the community of Kinraddie, which the Reverend Gibbon calls 'a rotten kailyard'. ${ }^{42}$ John Guthrie, Chris's father, looks at her lustily like 'a caged beast', paces outside her bedroom during 'the harvest madness', and bids her sleep with him as they had done 'in Old Testament times' ${ }^{43}$ Chris's mother Jean kills herself rather than face yet another pregnancy forced upon her by Guthrie's religious beliefs, and her children Dod and Alec are

\footnotetext{
${ }^{39}$ Craig, The Modern Scottish Novel, p. 62.

${ }^{40}$ Douglas Brown, The House with the Green Shutters, p. 216.

${ }^{41}$ Lewis Grassic Gibbon, Sunset Song (Edinburgh: Canongate, 2008), p. 24.

${ }^{42}$ Gibbon, Sunset Song, p. 84.

${ }^{43}$ Gibbon, Sunset Song, pp. 60, 72, 108.
} 
taunted at school: 'Daftie, daftie! Whose mother was a daftie? ${ }^{44}$ However, it is the village 'dafties' Andy and Tony who are the key to understanding the madness which overtakes a community in the grip of Calvinist repression. Andy, who appears to be genuinely mentally disturbed, runs amok one day through Kinraddie molesting girls, whereas Tony, who is described as having 'once been a scholar and written books and learned and learned till his brain fair softened and right off his head he'd gone', is more insightful as to the nature of his own and the community's malady, calling the local minister 'only a half-witted cleric'. ${ }^{4}$ Greeting Chae Strachan, one of the community's few genuinely good characters and 'a socialist creature' who believes in equality, Tony cries enigmatically: 'Ay, Chae, so the mills of God still grind?', a proverbial saying with classical antecedents used by the American poet Henry Wadsworth Longfellow in 'Retribution'. ${ }^{46}$ The retribution of 'a world gone mad' in war that tears Kinraddie apart and kills a generation of peasant farmers is suffered by a community ministered to by a hypocritical religion that renders learning futile (mere 'dirt') and love shameful. ${ }^{47}$ Andy and Tony are holy fools bearing the names of saints: Scotland's patron saint Andrew becomes in Andy the perverted sex instinct of a country inhibited by Calvinist doctrine, while Tony as the mystic Saint Anthony represents the repressed spiritual intelligence of a community that has lost its way in the material temptations of a modernising world.

The critique of Calvinism in Sunset Song clears the way for new forms of religion and new ideas of community in the following two novels of the Scots Quair trilogy: the Reverend Colquohoun's humane but ineffectual Christian socialism in Cloud Howe (1933) and Ewan's anti-humanist revolutionary communism in Grey Granite (1934). Much has been made of the purportedly inclusive, communitarian use of 'you' throughout A Scots Quair, wherein the

\footnotetext{
${ }^{44}$ Gibbon, Sunset Song, p. 65. Italics in original.

${ }^{45}$ Gibbon, Sunset Song, pp. 15-16, 198.

${ }^{46}$ Gibbon, Sunset Song, pp. 10, 204. Italics in original.

${ }^{47}$ Gibbon, Sunset Song, p. 236.
} 
community speaks through individual characters and characters voice the community. Thomas Crawford claims that 'self-referring you [he is using Graham Trengove's phrase] serves to dramatise a character's thought; while generic you, equivalent to "everybody", strengthens the impression of universality'. ${ }^{48}$ Cairns Craig has written of the 'You and I' central to the ethics of John Macmurray, whose philosophy releases the Self from the isolated ego to find existence in relation to the Other. As Craig explains, for Macmurray 'the Self is constituted in, through and by its relationships to others. [...] The Other is not an alien world antithetical to Self: Self is the Other in its relations'. ${ }^{49}$ Crawford's argument that there is a communal aspect to Gibbon's use of 'you' tends to imply the 'You and I' of Macmurray: the Self in relation to others. But Gibbon's 'you' is not 'You and I' but rather 'You as I', you instead of I - a subtle yet crucial difference. 'You as I' constitutes an inability to speak in the first person, to act as a fully self-determining agent in the world. The communal element of Gibbon's 'you' is that 'You as I' comes from and is shared by the whole community's near pathological incapacity to assert its Self, a situation arising from the precedence of Standard English. ${ }^{50}$ For instance, in Sunset Song Long Rob makes the point 'what a shame it was that folk should be shamed nowadays to speak Scotch', whereas Gordon counters that to advance materially people 'must use the English'. ${ }^{51}$ The movement from Scots to English, seen by Gordon as progress and by Long Rob as loss, indicates the demise of community at the hands of class-conscious individualism. Unable any longer to speak in the Scots language as an agent in the 'You and I' relation, the Self loses all self-identity as 'I' and retreats to the second-person 'you'. 'You as I' can be a way of not really speaking at all and can be

\footnotetext{
48 Thomas Crawford, 'Introduction', A Scots Quair, pp. vii-xii (pp. xi-xii). See also Graham Trengove, 'Who is you? Grammar and Grassic Gibbon', Scottish Literary Journal, 2.2 (1975), 47-62.

${ }^{49}$ Craig, The Modern Scottish Novel, p. 90. See also Cairns Craig, 'Beyond Reason - Hume, Seth, Macmurray and Scotland's Postmodernity', in Scotland in Theory: Reflections on Culture and Theory, ed. by Eleanor Bell and Gavin Miller (Amsterdam and New York: Rodopi, 2004), pp. 249-83.

${ }^{50}$ See Hanne Tange, 'Language, Class and Social Power in A Scots Quair', in The International Companion to Lewis Grassic Gibbon, ed. by Scott Lyall (Glasgow: Scottish Literature International, 2015), pp. 22-32.

${ }^{51}$ Gibbon, Sunset Song, p. 156. Italics in original.
} 
negatively interpreted as stemming from self-alienation and the proletarianisation of the Scottish subject and community. 'You as I' illustrates not the triumph of mythic Scottish communalism but the Scottish community's subordination. 'You as I' is indicative of nationas-class.

Class is central to Gibbon's opposition to Hugh MacDiarmid's modern Scottish Renaissance as a movement or community of writers with shared political and cultural aims, coalescing around the idea of an independent Scotland. Gibbon makes his hostility to the Scots Renaissance most clear in the Scottish Scene (1934) essay 'Glasgow': calling the movement for revival 'a homogenous literary cultus', he states that ' $[\mathrm{t}]$ here is nothing in culture or art that is worth the life and elementary happiness of one of those thousands who rot in the Glasgow slums'. ${ }^{52}$ Gibbon may wish not to belong to the Scots Renaissance, but his concern here with the Glasgow proletariat and urban life in the fictional Duncairn of Grey Granite shifts that movement's focus away from the small-town rural communities that were the background of many of its main protagonists, such as Gibbon and MacDiarmid, Nan Shepherd, Edwin Muir, Fionn MacColla, Neil Gunn, and Violet Jacob, and their work.

Willa Muir, born in Montrose of Shetland parentage, shared Gibbon's objections to the Scottish Renaissance as a unifying MacDiarmidian-nationalist movement. Her account of small-town Scottish community in Imagined Corners (1931) highlights the restrictive, claustrophobic nature of bourgeois family life for women. Set in the fictional town of Calderwick, and beginning in 1912, a year of feminist agitation and suffragette unrest prior to women fully winning the vote, ${ }^{53}$ Alison Smith suggests that Muir's novel arose from her discontented sense that there was no place in Scottish society for 'women who feel and

\footnotetext{
${ }^{52}$ Lewis Grassic Gibbon, 'Glasgow', in Lewis Grassic Gibbon and Hugh MacDiarmid, Scottish Scene, or The Intelligent Man's Guide to Albyn (London and Melbourne: Hutchinson, n.d.), pp. 114-25 (pp. 119, 124). See also Christopher Silver, 'Lewis Grassic Gibbon and Scottish Nationalism', in The International Companion to Lewis Grassic Gibbon, pp. 105-18.

${ }^{53}$ See Leah Leneman, A Guid Cause: The Women's Suffrage Movement in Scotland, 2nd rev. edn (Edinburgh: Mercat Press, 1995).
} 
think' ${ }^{54}$ The Calderwick community portrayed in Imagined Corners is one of stifling social convention warping individuality and sex relations. Indeed, as the idealistic Elizabeth Shand begins to feel disillusioned in her marriage to Hector, the narrator comments: 'Wives, in Calderwood, were dull, domestic commodities, and husbands, it was understood, were unfaithful whenever they had the opportunity,. ${ }^{55}$ Business success breeds manners and a correct middle-class way to behave; as Elise Mütze, recently returned to Calderwick from the continent, notes, Mabel, her brother John's wife, 'doesn't even know she's acting, ${ }^{56}$ Elise, formerly Lizzie Shand, for whom the God believed in by Calderwickians is 'merely an enforcer of taboos, and a male creature at that', escaped the restrictions of Calderwick's hypocritical Calvinist moral codes by leaving for Europe in her youth; on revisiting, she precipitates change in the community's relations, particularly in her true 'other half' Elizabeth, but also in herself, as she must learn to find peace with her younger self and her own relationship to the community. ${ }^{57}$ In this sense, transformation comes to the community from outside - from Elise's freeing continental influence - and from within, in that Elise is after all a native of Calderwick as well as someone who forces on others and herself an inner re-evaluation of life: as Elise realises, 'the one important thing in life [is] the integrity of the spirit'. ${ }^{58}$ Yet cleaving to such personal spiritual integrity, the desire always 'to know the truth, the truth', is what sends Ned Murray mad. ${ }^{59}$ Ned cannot be helped by his brother William, a Church of Scotland minister, who confesses to having 'been asleep' spiritually and is therefore no guide to the community's religious life. ${ }^{60}$ Consulting a doctor as to Ned's prospects, William is told: 'our imperfect civilization may have been partly responsible for

\footnotetext{
${ }^{54}$ Alison Smith, 'And Woman Created Woman: Carswell, Shepherd and Muir, and the Self-Made Woman', in Gendering the Nation: Studies in Modern Scottish Literature, ed. by Christopher Whyte (Edinburgh: Edinburgh University Press, 1995), pp. 25-48 (p. 44). Italics in original.

${ }_{55}^{55}$ Willa Muir, Imagined Corners, in Imagined Selves, ed. by Kirsty Allen (Edinburgh: Canongate, 1996), p. 117.

${ }^{56}$ Muir, Imagined Corners, p. 225.

${ }^{57}$ Muir, Imagined Corners, p. 185.

${ }^{58}$ Muir, Imagined Corners, p. 164.

${ }^{59}$ Muir, Imagined Corners, p. 178.

${ }^{60}$ Muir, Imagined Corners, p. 271.
} 
your brother's breakdown'. ${ }^{61}$ However, the real blame lies closer to home. Like the 'dafties' of Sunset Song, Ned is a weathervane for Calderwick's own spiritual ills, in light of which his collapse into pessimism and paranoia, the feeling that the community is out to get him, is, as the doctor explains, entirely fitting:

'That persecution mania nearly always accompanies obscure breakdowns. It's one of the symptoms. Considering the long biological history of man, and the fact that herd animals nearly always reject their sick, it's not surprising if an unhappy human fears that he's to be rejected by his herd. [...] All communities persecute, and in that light persecution mania is reasonable enough. ${ }^{62}$

While it is tempting to assume that Scottish society became increasingly secular in the early decades of the twentieth century, and that therefore the fictional accounts by Gibbon and Muir overstate the influence of Presbyterianism, T. M. Devine claims that in fact during the 1920s and 1930s 'membership of the Church of Scotland was reasonably stable', with the real collapse in Kirk-going not occurring until the $1960 \mathrm{~s} .{ }^{63}$ Many writers of the modern Scottish Renaissance were hostile to what they thought were Calvinism's harmful effects on the nation's spiritual and cultural health, ${ }^{64}$ but Imagined Corners and Sunset Song cannily spotlight the madness wrought by Calvinism on Scottish communities.

Although not usually associated with the Scottish Renaissance period, Muriel Spark's The Prime of Miss Jean Brodie (1961) is set mainly during the revival era in Thirties Edinburgh; indeed, Grassic Gibbon's characterisation of Edinburgh in this period as a 'disappointed spinster' chimes with the description of Jean Brodie as 'an Edinburgh spinster

\footnotetext{
${ }^{61}$ Muir, Imagined Corners, p. 205.

${ }^{62}$ Muir, Imagined Corners, p. 205.

${ }^{63}$ T. M. Devine, The Scottish Nation 1700-2000 (Harmondsworth: Penguin, 2000), p. 386.

${ }^{64}$ See Scott Lyall, “'That Ancient Self”: Scottish Modernism's Counter-Renaissance', European Journal of English Studies, 18.1 (2014), 73-85.
} 
of the deepest dye', while Edwin Muir's view of the Scottish capital in his 1935 Scottish Journey as 'a city of extraordinary and sordid contrasts' is also captured by Spark. ${ }^{65}$ Like the writers of the literary renaissance, Spark's novel links Calvinism and madness, or, at least, the pitiful self-delusion of Brodie who believes 'that God was on her side whatever her course'. ${ }^{66}$ The Prime of Miss Jean Brodie is a parodic Kailyard novel, centred on education, with middle-class girls rather than lower-class lads o' pairts; it also tells of the tragedy of apparently self-sustaining, inward-looking community - total community ${ }^{67}$ - as led by the teacher-dictator Jean Brodie. Calvinism is an enigma to the half-English Sandy Stranger, who as a schoolgirl in Edinburgh feels 'deprived' of a 'birthright' which 'pervaded the place in proportion as it was unacknowledged'. ${ }^{68}$ Baffled she may be by the religion's essential nature and its expression in Edinburgh, but it is Sandy alone among the 'corporate Brodie set' who discerns the links between the teacher, the city and Calvinism. Brodie, who claims descent from the William Brodie whose 'double life' was dramatised by Robert Louis Stevenson and W. E. Henley, shuns the communion of the Roman Catholic Church and 'thinks she is the God of Calvin'. ${ }^{69}$ Edinburgh's double life is demonstrated when Brodie takes her privileged Morningside and Bruntsfield girls on a trip through the Old Town; but for Brodie this is an historical tour in which she fails to see the community's poverty. In denouncing Brodie, Sandy is not only renouncing Calvinist Edinburgh, but also Brodie's aestheticisation of education and politics, which turns reality and imagination into sheer fantasy and Calvinism's elect/damned duality into fascism. Born as the Aesthetic Movement got under way in 1890 and dying just after World War Two, the route from aesthetics to fascism, mapped by Walter

\footnotetext{
${ }^{65}$ Lewis Grassic Gibbon, 'Glasgow', in Scottish Scene, p. 114. Spark, The Prime of Miss Jean Brodie, p. 26. Edwin Muir, Scottish Journey (Edinburgh and London: Mainstream, 1999), p. 9.

${ }^{66}$ Spark, The Prime of Miss Jean Brodie, p. 85.

${ }^{67}$ The American sociologist Robert Nisbet uses this phrase to describe totalitarian regimes in his 1953 The Quest for Community: A Study in the Ethics of Order and Freedom (Wilmington, Del: ISI Books, 2010), pp. 173-92.

${ }^{68}$ Spark, The Prime of Miss Jean Brodie, p. 108.

${ }^{69}$ Spark, The Prime of Miss Jean Brodie, pp. 40, 120, 85.
} 
Benjamin in his 1936 essay 'The Work of Art in the Age of Mechanical Reproduction', is central to Brodie's life. While Benjamin warns against the 'negative theology' of 'pure' art, advocating instead a revolutionary art, Spark's novel cautions against truth being confused with fiction and lampoons art that merely reproduces versions of its maker in the same manner as Brodie imposes her reactionary politics on her pupils. ${ }^{70}$ Sandy sees 'that the Brodie set was Miss Brodie's fascisti', just as Brodie's prime signifies not only the best (premenopausal) years of her life, which she sacrifices for her pupils, but the teacher as leader or dominant person, superior, cold and alone: Brodie, in contrast to Sandy's and Jenny's parents, has an indivisible prime rather than the relatedness of sexual intercourse, and questions the very meaning of 'social' when Eunice wants to absent herself from the set. ${ }^{71}$ For all her idiosyncrasies, and her scorn for 'the team spirit', Brodie does not encourage individualism in her charges but the propagation of types within an enclosed, self-regarding community. ${ }^{72}$ Significantly, it is the two non-elect girls of the set who die: Mary, who was not bright enough for Classics, is burnt to death in a hotel fire, and the 'outsider' Joyce Emily dies in Spain fighting for Franco on Brodie's encouragement. ${ }^{73}$ While the Kailyard dominie exerts a positive influence over the community to liberate the lad o' pairts, Brodie's totalitarian instincts have an altogether more malign ending.

\section{A Portrait of the Artist and the Community}

Religion and education as repressive forces are also a considerable factor in Alasdair Gray's Lanark. The semi-autobiographical Duncan Thaw, who suffers asthma and eczema, is made ill by an environment discouraging of his artistic ambitions. Knoxian Presbyterianism has

\footnotetext{
${ }^{70}$ Walter Benjamin, 'The Work of Art in the Age of Mechanical Reproduction', in The Norton Anthology of Theory and Criticism, ed. by Vincent B. Leitch and others (New York and London: Norton, 2001), pp. 11661186 (p. 1172).

${ }^{71}$ Spark, The Prime of Miss Jean Brodie, pp. 31, 16, 62.

${ }^{72}$ Spark, The Prime of Miss Jean Brodie, p. 78.

${ }^{73}$ Spark, The Prime of Miss Jean Brodie, p. 8.
} 
been blamed for a reputedly hostile attitude to creativity and the arts in Scotland, perhaps even any visible signifier of difference or 'specialness', and Lanark maintains the Scots Renaissance distrust of Calvinism. Knox glooms over Glasgow in the realist sections of the novel, where Thaw's mother has a view of Knox's statue from her ward in Glasgow's Royal Infirmary:

Below them stood the old soot-eaten Gothic cathedral in a field of flat black gravestones. Beyond rose the hill of the Necropolis, its sides cut into by the porches of the elaborate mausoleums, the summit prickly with monuments and obelisks. The topmost monument was a pillar carrying a large stone figure of John Knox, hatted, bearded, gowned, and upholding in his right hand an open granite book. The trees between the tombs were leafless, for it was late autumn. Mrs Thaw smiled and whispered wanly, 'I saw a funeral go in there this morning.' 'No, it's not a very cheery outlook. ${ }^{74}$

Knox is associated with sickness and death, not freedom and life, and in this dismal environment, Thaw, the budding artist, is frozen by repression. If Knox is petrified in stone, Thaw is petrified by an inheritance of Knoxian theology: anti-art and anti-sex. Yet as an artist he may hold the key to thawing his community through the use of the imagination. ${ }^{75}$

One of the novel's most quoted passages makes this point explicit. Thaw and his friend Kenneth McAlpin (who takes his name from the first King of Scots) climb a hill with a view of the city: “"Glasgow is a magnificent city," said McAlpin. "Why do we hardly ever

\footnotetext{
${ }^{74}$ Alasdair Gray, Lanark: A Life in 4 Books (London: Picador, 1991), p. 191.

${ }^{75}$ See Cairns Craig, 'Going Down to Hell is Easy: Lanark, Realism and the Limits of the Imagination', in The Arts of Alasdair Gray, ed. by Robert Crawford and Thom Nairn (Edinburgh: Edinburgh University Press, 1991), pp. 90-107.
} 
notice that?" "Because nobody imagines living here," said Thaw' ${ }^{76}$ Thaw believes that Glasgow has been poorly served in artistic and literary representation and this has had a negative effect on the citizenry's sense of themselves and their habitat, for 'if a city hasn't been used by an artist not even the inhabitants live there imaginatively'. ${ }^{77}$ Thaw may finally drown in his solipsistic self, but in theory he understands that the creation of art has communal implications. Art, in this view, imagines and re-imagines the community; without it the community remains dead to itself - a perspective that has been critically popular in Scotland during the last several decades, especially since the 1979 devolution referendum in particular, after which, only two years later, followed the publication of the enormously influential Lanark.

Thaw's story is similar to Mat Craig's in Archie Hind's The Dear Green Place (1966), cited in Lanark's index of plagiarisms. Like Thaw, Hind's character is a budding artist. Craig is also thwarted by his Glasgow environment, yet wishes to write the great Glasgow novel, as Gray has done with Lanark. Significantly, Mat Craig works in a slaughter house, which ties into Lanark's ideas of feeding and consumption, particularly in the fantasy sections of Gray's novel where humanity 'is the pie that bakes and eats itself' in a monstrous cannibalistic parable of the repressions and oppressions of capitalist individualism. ${ }^{78}$ Both Thaw and Lanark have difficulties loving in this competitive system: Thaw, the artist, is asocial, whilst Lanark, the ordinary everyman is more social. This split is reminiscent of Stephen Dedalus and Leopold Bloom in James Joyce's Ulysses (1922). Stephen, like Thaw, is the asocial artist, Bloom the everyman hero: both have problems loving or expressing love; both are characters in their country's modern epic novel, as Lanark is Scotland's Ulysses. But the parallels go deeper, and while Gray mentions Joyce's A Portrait of the Artist as a Young Man (1916) in the index of plagiarisms, significantly he does not mention Ulysses. In Ulysses

\footnotetext{
${ }^{76}$ Gray, Lanark, p. 243.

${ }^{77}$ Gray, Lanark, p. 243.

${ }^{78}$ Gray, Lanark, p. 62.
} 
Stephen as an artist needs to find common ground with others and be more grounded and 'ordinary' if his art is ever to be realised; Bloom on the other hand, the adman everyman, is described as having 'a touch of the artist' about him. ${ }^{79}$ As separate individuals these two figures never quite find balance in their own lives, but would do so by combining their respective virtues in one personality. This also applies to Thaw and Lanark. Thaw, like Stephen, has no romantic love or sex in his life; each is as sterile in this sense as his respective city and nation are perceived to be culturally. The post-Romantic 'artist' is mentally ill, a 'divided self' in R. D. Laing's phrase, because s/he is alienated and different from, not organically connected to, the community in a market society that monetises relations. ${ }^{80}$ To re-imagine the community s/he needs to be more in touch with the community and have more of the common touch. Community, for the artist, can only be realised in a unity with the common. To adopt Gavin Miller's term, Thaw needs to find communion with others for his art to flourish; without that, he and his art can only remain repressed and be a comment on their society's repression. ${ }^{81}$ Equally Lanark, who has some sort of social mission to understand the conditions of the Institute and Unthank and the machinations of Provan, needs to have more of the artist in his personality; he screams 'I'm not an artist!', refusing to recognise that side of himself, but his inflexibility, his very ordinariness, is the reason for Rima's departure and his own unhappiness. ${ }^{82}$

\section{Community contra Community}

Lanark is a pathbreaking critique of Hobbesian Anglo-British capitalism. But the novel also maps the links between personhood and environment, character and community in a manner that is ambivalently influenced by Robert Owen's A New View of Society (1813-16). For

\footnotetext{
${ }^{79}$ James Joyce, Ulysses (Harmondsworth: Penguin, 1992), p. 302.

${ }^{80}$ 'Ronald Laing's thoughts about the nature of madness appealed to many educated minds, including mine.' 'Of R. D. Laing', in Alasdair Gray, Of Me and Others (Glasgow: Cargo Publishing, 2014), pp. 205-07 (p. 205).

${ }^{81}$ Gavin Miller, Alasdair Gray: The Fiction of Communion (Amsterdam and New York: Rodopi, 2005).

${ }^{82}$ Gray, Lanark, p. 389.
} 
Owen it is the social system that is responsible for the formation of good or bad character, not the individual, and the way to develop good people is through the creation of properly supportive communities: 'the happiness of self, clearly understood and uniformly practised $[, . .$.$] can only be attained by conduct that must promote the happiness of the community'. { }^{83}$ An admirer of Jeremy Bentham, Owen's variety of utilitarianism illustrates that 'the very arguments of classical liberalism could and were readily turned against the capitalist society which they had helped to build' ${ }^{84}$ While the philanthropist reformer Owen put his theories to the test in founding the workers' community of New Lanark, there is neither a communitarian alternative to, nor personal escape from, the capitalist system in the dystopian Lanark. By the novel's publication in 1981, Thatcherite market deregulation and privatisation were well underway, the defeat of the miners' strike (1984-85) was on the horizon, and the very notion of community was being undermined ideologically through denial of 'society' ${ }^{85}$ Gray inhabited a community of writers - James Kelman, Agnes Owens, Tom Leonard, Jeff Torrington - whose vernacular style and focus on the Glasgow working class was declared in the 1980-90s as another defining renaissance in Scottish letters, but which drew criticism for its apparently narrow social and political focus. ${ }^{86}$ Kelman would remain radically committed to writing from a working-class community, yet early novels such as The Busconductor Hines (1984) and A Chancer (1985) centre on existential loners, while A Disaffection (1989) turns the noble Kailyard dominie into a cynical burnt-out teacher who can do little more for his pupils than warn them of the alienation to come upon leaving school.

\footnotetext{
${ }^{83}$ Robert Owen, A New View of Society And Other Writings (Harmondsworth: Penguin, 1991), p. 14. Italics in original.

${ }^{84}$ Eric Hobsbawm, The Age of Revolution, 1789-1848 (London: Abacus, 2014), p. 293.

${ }^{85}$ Margaret Thatcher, 'Aids, education and the year 2000!' ['There is no such thing as society'], interview for Woman's Own, 31 October 1987, pp. 8-10

<http://www.margaretthatcher.org/speeches/displaydocument.asp?docid=106689> [accessed 5 September 2015].

${ }^{86}$ See Douglas Dunn, 'Divergent Scottishness: William Boyd, Allan Massie, Ronald Frame', in The Scottish Novel Since the Seventies: New Visions, Old Dreams, ed. by Gavin Wallace and Randall Stevenson (Edinburgh: Edinburgh University Press, 1993), pp. 149-69.
} 
Francis Fukuyama's The End of History and the Last Man, published in 1992, assumed the triumph of liberal capitalism over alternative economic and political systems, a mentality mirrored in the junky subculture of Irvine Welsh's Trainspotting (1993). Like Kelman's teacher Patrick Doyle, Welsh's novel also sees education as a dead-end for the working class, especially in an Edinburgh controlled by the Merchant school network. Instead, Trainspotting's Leithers turn to popular culture, football and drugs. The callous ethics of capitalist individualism are endorsed by the novel's drug users: 'the real junky [...] doesnae gie a fuck aboot anybody else'; as the dealer Mother Superior says: 'Nae friends in this game. Just associates' ${ }^{87}$ This credo - 'Ah believe in the free market whin it comes tae drugs' - subscribes to no traditional political line, as the Sean Connery-obsessed Sick Boy explains:

... the socialists go on about your comrades, your class, your union, and society. Fuck all that shite. The Tories go on about your employer, your country, your family. Fuck that even mair. It's me, me, fucking ME, Simon David Williamson, NUMERO FUCKING UNO, versus the world, and it's a one-sided swedge. It's really so fucking easy ... Fuck them all. I admire your rampant individualism, Shimon. ${ }^{88}$

Yet, the novel works both with and against its characters in order to define certain principles, being anti British Protestant imperialism, racism and sexism (although this last can seem difficult to discern in the welter of male violence and misogyny). Coming from or identifying with the traditionally Catholic, Irish-immigrant, Hibernian-supporting community centred round Easter Road and Leith, the main characters are already outside the city's hegemonic norm. As Renton's 'Choose life' mantra reveals, the junkies of Trainspotting also form a

\footnotetext{
${ }^{87}$ Irvine Welsh, Trainspotting (London: Vintage, 2004), pp. 7, 6.

${ }^{88}$ Welsh, Trainspotting, pp. 310, 30. Italics in original.
} 
nihilistic community of individuals ranged against what they regard as the equally dysfunctional bourgeois values of family life, consumerism and 'getting on'. Theirs is a (non)community opposed to the pretence that middle-class individualism was ever anything other than a community of self-interest. Trainspotting, a massively successful book and film, is both critique of and capitulation to the capitalism that eviscerates community.

\section{The End of Community?}

As Kirstin Innes wrote in 2007, 'Scotland's literary landscape has never quite recovered from Trainspotting' ${ }^{89}$ Perhaps ironically, Welsh's Edinburgh novel has arguably most influenced the work of many of those contemporary writers Alan Bissett calls the 'New Weegies' ${ }^{90}$ those based in and/or setting their work in Glasgow, such as Bissett's Death of a Ladies' Man (2009), Suhayl Saadi's Scots-Asian fusion Psychoraag (2004), and Zoë Strachan's Negative Space (2003), in which the narrator leaves Glasgow for Orkney to find healing after her brother's death, although Alan Warner's Morvern Callar (1995), filmed by Lynne Ramsay (2002), bucks the urban trend, positing an alternative rave community to the dystopic Kailyard of the Western Highland Port. ${ }^{91}$ While Innes's statement implies the liberating power of Trainspotting, it can also be read more ambivalently. The apparent acceptance of 'end-of-history' postmodernism is troubling for the novel, a genre which has traditionally narrated communality. If community is under threat from laissez-faire individualism, neoliberalism, and cosmopolitan pop culture, then the end of community is best represented by a post-genre text such as Ewan Morrison's Tales from the Mall (2012). Like the mall,

\footnotetext{
${ }^{89}$ Kirstin Innes, 'Mark Renton's Bairns: Identity and Language in the Post-Trainspotting Novel', in The Edinburgh Companion to Contemporary Scottish Literature, ed. by Berthold Schoene (Edinburgh: Edinburgh University Press, 2007), pp. 301-09 (p. 301).

${ }^{90}$ Alan Bissett, 'The "New Weegies": The Glasgow Novel in the Twenty-first Century', in The Edinburgh Companion to Contemporary Scottish Literature, pp. 59-67.

${ }^{91}$ See Scott Lyall, 'The Kailyard's Ghost: Community in Modern Scottish Fiction', in Roots and Fruits of Scottish Culture: Scottish Identities, History and Contemporary Literature, ed. by Ian Brown and Jean Berton (Glasgow: Scottish Literature International, 2014), pp. 82-96 (pp. 92-93).
} 
Morrison's book contains '[a]ll you'll ever need, under one roof': fiction; histories of the mall; real-life events. ${ }^{92}$ Tales from the Mall mirrors capitalism in its range of content choice, its merging of styles and genres, and its lack of coherent narrative structure - a point made by Morrison:

$[\mathrm{O}]$ ur era has no narrative; all that we require from a story - the struggle of the individual against all odds, towards a greater goal - is increasingly hard to envisage in an economy that undermines the lifelong project and in its place offers only quick fixes. It may be that consumerism and the struggle for daily survival in a deregulated job market of all-against-all has reduced our lives to short-term personal goals without a broader collective narrative. ${ }^{93}$

Like Lanark, the style of the book, with no logical beginning, structure or conclusion, can be described as postmodern, yet the contents can be seen as opposing some of the symptoms of postmodernity, such as mallification.

Morrison's guru in understanding postmodernity is Zygmunt Bauman, who defines the postmodern era as one of 'liquid modernity'. 'What makes modernity "liquid"', according to Bauman, 'is its self-propelling, self-intensifying, compulsive and obsessive "modernization", as a result of which, like liquid, none of the consecutive forms of social life is able to maintain its shape for long'. ${ }^{94}$ This is very reminiscent of The Communist Manifesto's idea that due to the revolutionary production relations of nineteenth-century capitalism 'all that is solid melts into air' ${ }^{95}$ However, while in the classic Marxian period of the nineteenth century, which Bauman calls 'heavy modernity', individuals were

\footnotetext{
${ }^{92}$ Ewan Morrison, Tales from the Mall (Glasgow: Cargo Publishing, 2012), p. 5.

${ }^{93}$ Morrison, Tales from the Mall, p. 9.

${ }^{94}$ Zygmunt Bauman, Culture in a Liquid Modern World, trans. by Lydia Bauman (Cambridge: Polity, 2012), p. 11.

${ }^{95}$ Karl Marx and Friedrich Engels, The Communist Manifesto (London: Vintage, 2010), p. 25.
} 
characteristically economic producers, 'postmodern society engages its members primarily in their capacity as consumers' ${ }^{96}$ If the distinguishing identity of the liquid modern era is that of the consumer, then the presiding characteristic of the liquid modern world is impermanence: impermanent relationships, employment, location, identities, and so on. Just as neoliberal capital is fluid and respects no borders, so the topos of postmodernity is a liquid impermanence.

Bauman argues that ' $[t]$ he function of culture is not to satisfy existing needs, but to create new ones' ${ }^{97}$ Tales from the Mall depicts the damaging results of the consumerist ethos for relationships and communities. Relationship breakdown is encouraged by capitalism creating never-ending consumer demand: 'now they've exhausted the family market, they're doubling their money with divorce', claims a character in 'Exits' ${ }^{98}$ Liquid modern relationships embody 'the mall within': transitoriness, lack of commitment, desire over need, and personal choice as a signifier of freedom. ${ }^{99}$ Malls - the American name for shoppingcentres is significant - are symptomatic of globalisation, which results in the loss of a centre in individual, local/regional and national life, the consumerisation of personal and cultural space. As 'The Empty Space' indicates, malls literally have no centre (a disorientation tactic meaning there is nowhere to collect): 'the centre is a space, not a place'. ${ }^{100}$ Metaphorically and literally, 'there is something empty at the heart of consumerism'. ${ }^{101}$ David Harvey argues that malls "instantiate rather than critique the idea that "there is no alternative"" to capitalism, with the ubiquity of the mall having done 'as much to signal the end of history as the collapse of the Berlin Wall ever did'. ${ }^{102}$ The mall is a place that is a no place. Such decentring destroys communities and the very idea of community. The globalised world of 'Redacted',

\footnotetext{
${ }^{96}$ Zygmunt Bauman, Liquid Modernity (Cambridge: Polity, 2012), p. 76.

${ }^{97}$ Bauman, Culture in a Liquid Modern World, p. 17.

${ }^{98}$ Morrison, Tales from the Mall, p. 204.

${ }^{99}$ Morrison, Tales from the Mall, p. 207.

${ }^{100}$ Morrison, Tales from the Mall, p. 79.

${ }^{101}$ Morrison, Tales from the Mall, p. 79.

${ }^{102}$ David Harvey, Spaces of Hope (Edinburgh: Edinburgh University Press, 2002), p. 168.
} 
in which after '[e]ight hours on a plane [...] you haven't moved a mile', witnesses the death of a local town centre due to the opening of a mall that in contrast is 'busy, bustling, as if all the townsfolk have moved here'. ${ }^{103}$

Although Tales from the Mall instances acts of personal resistance against mallification, the ultimate act of opposition - the burning down of the mall in 'Borders' - is accidental, while the 'Twenty Top Tips for Brightening your Day in the Mall' details anarchist pranks rather than structured opposition. Morrison may be right to allege that ' $[t]$ he mallification of my country [Scotland] is an historic event, as important as the Jacobite Rebellion or the Highland Clearances', but his claim that '[t]he literature of my country is vehemently opposed to what it sees as a takeover of our national identity by multi-national forces' implies some sort of corporate 'Scottish Literature' as well as the communal Scottish myth outlined by McCrone. ${ }^{104}$ However, the activism of the Scottish independence referendum suggests a revitalisation of grassroots, community hall politics, and the redefinition of how we understand community and its relation and resistance to hegemonic politics.

One of the most significant and divisive aspects of the 2014 independence debate was the emergence of online communities as a means to campaign and propagandise for a Yes or No vote. 'Yes' in particular drew much support from culturalist communities such as National Collective and Bella Caledonia to challenge the dominant narratives of organisations such as the $\mathrm{BBC}$ and much of the Scottish and London print media, whose agenda was deemed to be Unionist by many Yes supporters. ${ }^{105}$ 'New communications technologies have catalyzed new styles for imagining and organizing communities of all

\footnotetext{
${ }^{103}$ Morrison, Tales from the Mall, pp. 60, 69.

${ }^{104}$ Morrison, Tales from the Mall, pp. 8, 10.

${ }^{105}$ See Iain Macwhirter, Disunited Kingdom: How Westminster Won a Referendum but Lost Scotland (Glasgow: Cargo Publishing, 2014), pp. 51-71, and Democracy in the Dark: The Decline of the Scottish Press and How to Keep the Lights On (Edinburgh: Saltire, 2014). For more on the referendum in relation to the British constitution, see Michael Gardiner, Time and Action in the Scottish Independence Referendum (Basingstoke: Palgrave Macmillan, 2015).
} 
sorts, including explicitly political communities', argues Patricia Hill Collins, for whom virtual communities can 'unsettle notions of a top-down public sphere, where elites control knowledge and public information'. ${ }^{106}$ Whether such virtual communities, prone as they are to echolalia and self-promotion, adequately replace, or are merely revenants of, an old-school communitarian politics, or, indeed, actually suggest the triumph of hyperreal individualism, remain open questions. Benedict Anderson famously proposed that the 'basic morphology' of what would become the modern nation emerged in 'the convergence of capitalism and print technology' ${ }^{107}$ In a contemporary era that has seen traditional print media challenged by the rise of virtual communities, Anderson's equation, and what it means for nationhood and nationalism, needs to be reassessed. While Morrison's book would seem to suggest the end of community, the virtual communities established during the independence referendum show that the ends of community have emerged from the terrain of Scottish myth to become politically proactive communities in practice. These new imagined communities have contributed to a reshaping of the idea of community and the imagined community that is Scotland.

\footnotetext{
${ }^{106}$ Patricia Hill Collins, 'The New Politics of Community', American Sociological Review, 75.1 (2010), 7-30 (p. 17).

${ }^{107}$ Benedict Anderson, Imagined Communities: Reflections on the Origin and Spread of Nationalism (London and New York: Verso, 2006), p. 46.
} 